\title{
Miranda
}

Revue pluridisciplinaire du monde anglophone /

Multidisciplinary peer-reviewed journal on the English-

speaking world

$14 \mid 2017$

Early American Surrealisms, 1920-1940 / Parable Art

\section{Vanessa Bell}

Dulwich Picture Gallery, London, 8 February - 4 June 2017

\section{Claudia Tobin}

\section{(2) OpenEdition}

\section{Journals}

Electronic version

URL: http://journals.openedition.org/miranda/10070

DOI: 10.4000/miranda.10070

ISSN: 2108-6559

\section{Publisher}

Université Toulouse - Jean Jaurès

\section{Electronic reference}

Claudia Tobin, "Vanessa Bell ", Miranda [Online], 14 | 2017, Online since 18 April 2017, connection on 16 February 2021. URL: http://journals.openedition.org/miranda/10070 ; DOI: https://doi.org/10.4000/ miranda. 10070

This text was automatically generated on 16 February 2021.

\section{(c) $(1) \&$}

Miranda is licensed under a Creative Commons Attribution-NonCommercial-NoDerivatives 4.0 International License. 


\title{
Vanessa Bell
}

Dulwich Picture Gallery, London, 8 February - 4 June 2017

\author{
Claudia Tobin
}

Vanessa Bell takes centre stage at the Dulwich Picture Gallery in London. Somewhat shockingly, this is Bell's first major monographic exhibition and it sets out to present her as a pioneer and progressive. We encounter her work at its most radical and exciting, predominantly in the period of intensified experimentation during the 1910 s. She emerges at the vital centre of Bloomsbury's artistic network, her scope and range demonstrated across different genre and media.

2 Bell's experiment in pure abstraction in late 1914 and early 1915 is often overlooked or considered apart from her figurative work. However, she pushed the simplification of form and use of non-naturalistic colour to its limits in both painting and in decorative design, venturing further into pure abstraction than many of her European contemporaries at this time. In the wake of the 1910 and 1912 Post-Impressionist exhibitions, which featured modern European painters including Cézanne, Matisse and Van Gogh, Bell found new freedoms in form and colour. As she later recalled, she was impelled to 'destroy the solidity of objects' and revelled in their dissolution into colour. ${ }^{1}$ This exhibition is a rare opportunity to see works made at the peak of her experimental phase. In Room 2 we encounter Abstract Composition with its bold colour contrasts and authoritative central black square, alongside Composition, a textured geometric collage which reveals her affinity with the papier collé techniques employed by Picasso and Braque.

3 The exhibition aims, and rightly so, to show Bell alone and on her own terms. We should not forget however, that collaboration was central to her project. Bell worked closely with Duncan Grant creating innovative designs for the Omega workshops, the interior design company that she co-founded with the art historian Roger Fry in 1913. If the Omega designs and printed linens feel as fresh and contemporary as ever, England was not ready for them, and the workshops saw an untimely end to operations in 1919. They 'would have succeeded in any other European country', Fry lamented. ${ }^{2}$ Bell's printed linens testify to her place alongside - even as a forerunner - to women designer contemporaries in Europe, such as Sonia Delaunay. 
Bell's adeptness as an 'innovative home-maker' and 'bohemian mother' is emphasised throughout the exhibition narrative. Whether in Bloomsbury or Sussex she created an atmosphere in which creativity could flourish, and tolerance prevailed. This does not so much counter associations of Bell and the domestic, but it does offer a broader sense of what this might mean. Her portraits cast a light at once critical and celebratory on her artistic and literary circle. She is revealed as an acute observer of gesture and posture, perhaps most strikingly in the elliptical, blurred rendering of features in her portraits of her sister, Virginia Woolf. Her apparent resistance to hierarchical distinctions between the decorative and fine arts is also well demonstrated: we encounter printed linens, paintings, and book cover designs, alongside works from later decades, which testify to her integration of Omega products into the spaces of the home. The hallucinatory scale and heightened colour of Tea Things is reminiscent of Paul Nash's surreal depictions of objects, but it captures the spirit of Bell's domesticity - vibrant, daring, and irreverent in its transformation of the everyday.

The non-linear chronology of this exhibition feels appropriately modernist, but the thematic arrangement of works from disparate periods sometimes disrupts the possibility of tracing nuances in Bell's stylistic evolution. Nevertheless, the third room is persuasive in its organisation around her contribution to the genre of still life. We move from the quiet control and understated eloquence of Iceland Poppies (c. 1908-9) to the kaleidoscopic exuberance of Oranges and Lemons (1914). On the opposite wall, in the large and enigmatically titled The Other Room, the familiar background blocks of colour hollow out a striking central emptiness, which contributes to the sense of estrangement between three immobile figures who almost become still lifes in themselves. Matisse's presence is keenly felt here and elsewhere. Bell had visited his studio in the spring of 1914 and admired his work in the years leading up to this period - but this was no simple case of imitation. Her strongest works see her absorbing French modernism and making it her own.

6 The tension between intimacy and estrangement charge many of the works in this exhibition. In the final room, A Conversation captures a moment of rapt intimacy between three women. It was suggestive to Woolf, who imagined a version of the painting 'in prose'. On the opposite wall is Bell's celebrated Studland Beach. It is one of her most emotionally eloquent works with its stretch of empty beach and sky and the rigid isolation of the standing figure, back turned away from the viewer, as if on the threshold of a transformative encounter. Often heralded as the beginning of Bell's most experimental period, the painting is seen here alongside preparatory works, revealing her process of radical simplification. Placed at the very end of the exhibition, it made me want to retrace my steps.

\section{NOTES}

1. Vanessa Bell, letter to Roger Fry, 19 September 1923, in Regina Marler (ed.). Selected Letters of Vanessa Bell. London and New York: Bloomsbury, 1994, p.272. 
2. Roger Fry, "The Present Situation," unpublished lecture, 1924, King's 1/111. Quoted by Christopher Reed in Bloomsbury Rooms: Modernism, Subculture, and Domesticity. New York: Bard Graduate Center for Studies in the Decorative Arts, Design, and Culture, 2004, p.111.

\section{INDEX}

Mots-clés: abstraction, couleur, Omega workshops, arts décoratifs, peinture Keywords: abstraction, colour, Omega workshops, decorative arts, painting Subjects: British painting

\section{AUTHORS}

\section{CLAUDIA TOBIN}

Leverhulme Early Career Fellow in English at the University of Cambridge and a Research Associate at Jesus College 